
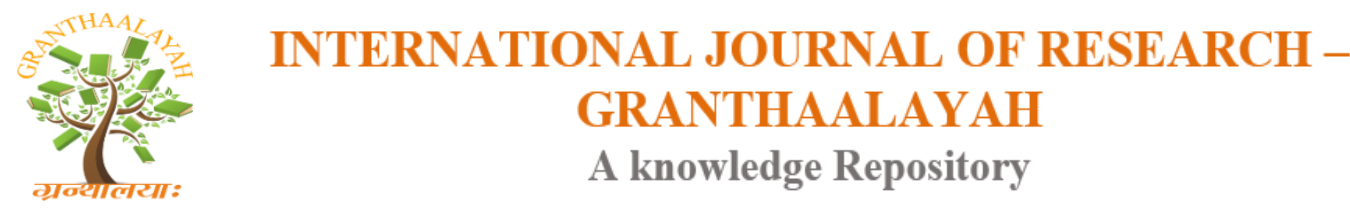

Science

\title{
A CLINICAL EFFECT OF AABHADI CHOORNA ON KATISHOOLA W.S.R. TO ASTHIMAJJAGAT VATA - A CASE STUDY
}

\author{
Dr. Pooja Santosh Gugale ${ }^{* 1}$, Dr. Mukund .M. More ${ }^{2}$ \\ ${ }^{* 1}$ M.D. (Scholar), Kaychikitsa Department, S.G.R. Ayurveda College, Solapur, India \\ ${ }^{2}$ Ph.D (Ayurved), Kaychikitsa Department, S.G.R. Ayurveda College, Solapur, India
}

\begin{abstract}
Katishoola is one of the vatavyadhi and it is the commonest disorder found in clinical practice. According to Ayurveda, Katishoola is the diseases with pain in lumber region. Katishoola can be equated with low back pain .The allopathic system of medicine use non-steroidal antiinflammatory drugs, analgesics, which is not safe and effective for katishoola.

A 60 year old male patient had suffering from progressive pain in lower back and difficulty in bending forward over $25^{\circ}$ and tingling sensation in both leg since last 12 months. X-ray of lumbo-sacral region indicated that patient was suffering from reduced L4-L5 intervertebral disc space and bony ankylosis of L4-L5 and degenerative changes in spine. He was taken modern treatment but doesn't get satisfactory relief even.

For Ayurvedic treatment he came at opd of kaychikitsa department of Seth Sakharam Nemchand Jain Ayurvedic Hospital, Solapur. He was treated for 21 days with 3 times treatment follow up. The response of the treatment was recorded and therapeutic effects were evaluated through symptomatic relief. Clinical symptoms were significantly reduced and degree of anterior flexion increased from $25^{\circ}$ to $90^{\circ}$.

This regimen is effective in successfully treating katishoola by helping to reduce the symptoms and improving the degree of anterior flexion.
\end{abstract}

Keywords: Katishoola; Low Back Pain; Aabhadi Choorna; Asti-Majjagat Vata.

Cite This Article: Dr. Pooja Santosh Gugale, and Dr. Mukund .M. More. (2018). "A CLINICAL EFFECT OF AABHADI CHOORNA ON KATISHOOLA W.S.R. TO ASTHIMAJJAGAT VATA - A CASE STUDY.” International Journal of Research - Granthaalayah, 6(3), 172-175. https://doi.org/10.29121/granthaalayah.v6.i3.2018.1511.

\section{Introduction}

Katishoola is a disease which is mainly caused by vitiation of vata dosha. A successful life of every individual is greater depend upon locomotion i.e. ability of using joints and bones. Katishoola cripples the freedom of movements. 
The 2010 global burden of disease study has estimated that low back pain is one of the top ten disease. It is difficult to estimate the incidence of low back pain (Katishoola) as now a days the incidence of first episode is by the early adulthood and symptom tend to recur overtime.

In Ayurveda, Katishoola has not been described as individual disease. Katishoola has been denoted by different terms in nanatmaj vata vyadhis as katigraha, shronibheda, trikgraha ${ }^{(1)}$. Kati is one of the region of vatadosha ${ }^{(2)}$ and vatadosha is responsible for katishoola. While describing sandhishoola in Ayurvedic texts it is clearly mentioned that "Sandhishoola" (3) is one of the symptom of "Asthimajjagata vata" (4). Laying special emphasis on this particular lakshana we have chosen katisandhi as a reference for this study.Common cause of Katishoola (low back pain) include lumbar strain, nerve irritation, lumbar radiculopathy, etc.

Aabhadi choorna contains mainly Vatshamak dravyas and also having properties of Balya, Deepan, Pachan and Asthisandhankar. This combination may help in sampraptibhanga of Asthimajjagata vata and hence relieve katishoola.

\subsection{Case Report}

A 60 year old man, who attended the Outdoor Patients Department of S.S.N.J. Ayurved Hospital, Solapur for treatment of his lower back pain was selected and admitted to the ward. He had a 12 month history of progressively increasing pain in lower back and both buttocks and tingling sensation in both legs. He was an otherwise healthy farmer, capable of doing heavy work. He had no history of trauma and his symptoms have increased gradually.

On physical examination, patient had little discomfort in buttocks on turning to the lateral side. Straight leg raising test was negative in both legs. He could flex the body forward up to $25^{\circ}$. Motor and sensory functions were normal in right and left legs and both deep and superficial reflexes were also normal.

All details of the patient including present history, past history, treatment history, dietary habits, lifestyle and addictions were recorded before the treatment. Necessary examinations and X-ray in lumbo sacral region were done and findings were recorded. Patient was kept on a normal diet without any specific restrictions and was advised not to lift any weights. The patient was treated with Aabhadi choorna for 21 days.

\section{Materials and Methods}

\subsection{Materials}

Aushadhi yoga: - AABHADI CHOORNA ${ }^{(5)}$ 
Table 1 : Showing contains of Aabhadi choorna

\begin{tabular}{|l|l|l|l|}
\hline SR.NO. & DRUG & FORM & \\
\hline 1 & Aabha & Choorna & \\
\hline 2 & Rasna & Choorna & \\
\hline 3 & Guduchi & Choorna & \\
\hline 4 & Shatavari & Choorna & \\
\hline 6. & Shatapushpa & Choorna & Same \\
quantity \\
\hline 7. & Ashwagandha & Choorna & \multirow{4}{|}{} \\
\hline 8 & Hapusha & Choorna & \\
\hline 9 & Vrudhhadaru & Choorna & \\
\hline 10 & Yavani & Choorna & \\
\hline 11 & Ajamoda & Choorna & \\
\hline
\end{tabular}

\section{Choorna Nirman Vidhi ${ }^{(6)}$}

The raw material in choorna form will be collected from S.S.N.J. Ayurved Aoushadhalaya Trust's Ayurved Rasashala (ISO certified company) of Particles size of 80-100 mesh. All dravya will be taken as per the proportion mentioned in above chart. They will mix with the help of khalva yantra. Phytochemical analysis of thus prepared choorna will be done before use.

Dose $\quad: \quad 4 \mathrm{gm} \times$ twice in a day.

Anupan : Koshnajala

Aushadhi-Sevan Kala : Adhobhakt (Vyan Udan kala)

Route of Administration : Oral.

Duration : 21 days.

Follow up $\quad: \quad$ After every 7 days

\subsection{Methods}

Center of study: S.S.N.J.Ayurved Rugnalaya, solapur.

Method of sampling: simple randomized.

\section{Observation}

Response to the treatment was recorded and therapeutic effects were evaluated by symptomatic relief of the patient. It was observed that the patient's clinical symptoms were reduced gradually during the treatment period and degree of anterior flexion increased from $25^{\circ}$ to $90^{\circ}$.

Table 2 : Showing Evaluation of clinical symptoms

\begin{tabular}{|l|l|l|}
\hline SYMPTOMS & BEFORE TREATMENT & AFTER TREATMENT \\
\hline Pain in low back & Grade 4 & Grade 1 \\
\hline Pain in both buttocks & Grade 3 & Grade 0 \\
\hline Tingling sensation & Grade 3 & Grade 1 \\
\hline Degree of anterior flexion & $25^{\circ}$ & $90^{\circ}$ \\
\hline
\end{tabular}




\section{Discussion}

- Discussion on vhaydhi: According to the Ayurveda, shoola (pain) occurs due to vitiation of vata dosha ${ }^{(7)}$. Vata Dosha is vitiated by srotas awarodata (obstruction of channels) and Dhatu kshaya (depletion of tissues/ malnutrition). In kati-shoola, Apana vata is mainly involved. So, the aim of the treatment is to pacify vitiated vata dosha especially Apana vata.

- Discussion on Aushadhi yoga: Ingredients of Aabhadi choorna have the properties of Vatashamaka (Pacify the vitiated vata dosha), Vedana sthapana (Sedative), Shoola Prashamana (Analgesic), Balya (Promote strength), Rasayana (Rejuvenation), Asthisandhankar (Improving qualities of bones and reformation of wasting tissues). As the drugs used in the present study have above properties, they are beneficial for diseases originated by vitiation of vata dosha. Patient suffering from kati shoola showed a significant symptomatic relief with this treatment regimen.

\section{Result}

With use of Abhadi choorna all symptoms of katishool reduce and improving the degree of anterior flexion.

\section{Conclusion}

It is concluded that this treatment regimen completely or partially relieves the symptoms in katishoola. This medicine can be utilized in treating patients who are suffering from katishoola to reduce both signs and symptoms successfully and with greater effectiveness. It is proposed that the therapy may be accepted as a treatment method of katishoola.

\section{References}

[1] Agnivesha; Charak Samhita; Hindi translation by, Brahmananda Tripathi ; published by, Chaukhambha Surbharati Prakashan, Varanasi; Reprint -2016; Part-1; Sutra Sthana; 20;11;p-390.

[2] Sartha Vagbhata; Marathi translation by, Ganesh Krushna Garde; published by, Rajesh Prakashan, Kathrud, Pune; Reprint-2009; Sutra Sthan; 12; 1; p-54.

[3] Agnivesha; Charak Samhita; Hindi translation by, Brahmananda Tripathi; published by, Chaukhambha Surbharati Prakashan, Varanasi; Reprint-2011; Part-2; Chikitsa Sthana; 28:33; p942.

[4] Agnivesha; Charak Samhita; Hindi translation by, Brahmananda Tripathi; published by, Chaukhambha Surbharati Prakashan, Varanasi; Reprint-2011; Part-2; Chikitsa Sthana; 28:33; p942.

[5] Vangasen Samhita (Chikitsasar Sangraha); Hindi translation by, Dr. Rajiv Kumar Ray; published by, Prachya Prakashan, Varanasi; First Edition-1983; Aamvata Rogadhikara; 66-68; p-325.

[6] Sharangdhar Samhita; Hindi translation by, Brahmananda Tripathi; published by, Chaukhambha Surbharati Prakashan, Varanasi; Reprint-2015; Madhyam Khanda; 6:1; p-116.

[7] Agnivesha; Charak Samhita; Hindi translation by, Brahmananda Tripathi; published by, Chaukhambha Surbharati Prakashan, Varanasi; Reprint-2016; Part-1; Sutra Sthana; 20;12; p-391.

*Corresponding author.

E-mail address: poojagugale14@gmail.com/mukundmore@ yahoo.in 